Research article

Open Access

\title{
Design, Synthesis and Biological Evaluation of New 5,5-Diarylhydantoin Derivatives as Selective Cyclooxygenase-2 Inhibitors
}

\author{
Afshin ZARGHI * ${ }^{1}$, Farin SATTARY JAVID ${ }^{1}$, Razieh GHODSI ${ }^{1}$, \\ Orkideh G. DADRASS ${ }^{2}$, Bahram DARAEI ${ }^{3}$, Mehdi HEDAYATI ${ }^{4}$
}

${ }^{1}$ Department of Pharmaceutical Chemistry, School of Pharmacy, Shahid Beheshti University of Medical Sciences, Tehran, Iran.

${ }^{2}$ Department of Pharmaceutical Chemistry, School of Pharmacy, Azad University, Tehran, Iran.

${ }^{3}$ Department of Toxicology, Tarbiat Modarres University, Tehran, Iran.

${ }^{4}$ Research Institute for Endocrine Sciences, Shahid Beheshti University (M.C), Tehran, Iran.

* Corresponding author. E-mail: zarghi@sbmu.ac.ir (A. Zarghi)

Sci Pharm. 2011; 79: 449-460

doi:10.3797/scipharm.1104-20

Published: $\quad$ July $25^{\text {th }} 2011$

Accepted: $\quad$ July $25^{\text {th }} 2011$

Received: $\quad$ April $25^{\text {th }} 2011$

This article is available from: http://dx.doi.org/10.3797/scipharm.1104-20

(C) Zarghi et al.; licensee Österreichische Apotheker-Verlagsgesellschaft m. b. H., Vienna, Austria.

This is an Open Access article distributed under the terms of the Creative Commons Attribution License (http://creativecommons.org/licenses/by/3.0/), which permits unrestricted use, distribution, and reproduction in any medium, provided the original work is properly cited.

\begin{abstract}
A new group of 5,5-diarylhydantoin derivatives bearing a methylsulfonyl COX-2 pharmacophore at the para position of the C-5 phenyl ring were designed and synthesized as selective COX-2 inhibitors. In vitro COX-1/COX-2 inhibition structure-activity relationships identified 5-[4-(methylsulfonyl)phenyl]-5-phenylhydantoin (4) as a highly potent and selective COX-2 inhibitor (COX-2 $\mathrm{IC}_{50}=$ $0.077 \mu \mathrm{M}$; selectivity index $>1298)$. It was more selective than the reference drug celecoxib (COX-2 $I_{50}=0.060 \mu \mathrm{M}$; selectivity index $\left.=405\right)$. A molecular modeling study where 4 was docked in the binding site of COX-2 indicated that the $p-\mathrm{MeSO}_{2} \mathrm{COX}-2$ pharmacophore group on the C-5 phenyl ring is oriented in the vicinity of the COX-2 secondary pocket. The results of this study showed that the type of substituent on the N-3 hydantoin ring substituent is important for COX-2 inhibitory activity.
\end{abstract}

\section{Keywords}

5,5-Diarylhydantoin derivatives • COX-2 inhibition • Molecular modeling studies • SAR 


\section{Introduction}

Non-steroidal anti-inflammatory drugs (NSAIDs) are widely utilized for the treatment of various inflammatory conditions such as rheumatic fever, rheumatoid arthritis and osteoarthritis. These drugs are competitive inhibitors of cyclooxygenase (COX), a rate limiting enzyme that mediates the bioconversion of arachidonic acid to inflammatory prostaglandins (PGs) $[1,2]$. COX is a membrane-bound heme protein which exists at least in two different isoforms, COX-1 and COX-2 [3]. COX-1, described as a "housekeeping" enzyme, is normally expressed in the gastrointestinal tract, kidneys and platelets. Under the influence of COX-1, prostaglandins maintain the integrity of the gastric mucosa, mediate normal platelet function and regulate renal blood flow [4]. The isoenzyme COX-2 is primarily associated with inflammation. Cytokines and growth factors increase the expression of COX-2, mainly at inflammatory sites, producing prostaglandins that mediate inflammation, pain and fever [5]. However, because NSAIDs inhibit both isoforms of cyclooxygenase (COX) their use is often accompanied by gastrointestinal side effects and renal function suppression [6]. It is known that selective COX-2 inhibitors can provide antiinflammatory agents devoid of the undesirable effects associated with classical non selective NSAIDs. Moreover, recent studies indicating the place of COX-2 inhibitors in the prevention of several cancer types such as colon, breast, lung and prostate cancers [7-10] and neurodegenerative diseases such as Parkinson [11] and Alzheimer's [12] diseases still continues to attract investigations on development of COX-2 inhibitors. 1,2-Diarylheterocycles, and other central ring pharmacophore templates, have been extensively studied as the most important selective COX-2 inhibitors. Several series of selective COX2 inhibitors belonging to the 1,2-diaryl class of compounds containing different heterocyclic and carbocyclic moieties as a central scaffold have been developed. All these tricyclic molecules possess a characteristic sulfonyl group such as a para- $\mathrm{SO}_{2} \mathrm{NH}_{2}$ or a para$\mathrm{SO}_{2} \mathrm{Me}$ substituent on one of the phenyl rings which plays an important role on COX-2 selectivity [13]. Celecoxib and rofecoxib are two well-known selective COX-2 inhibitors belong to COXIBs class $[14,15]$. However, the market withdrawal of some COXIBs such as rofecoxib due to increase the risk of heart attack and cardiovascular side effects [16] encourages the researchers to explore new selective COX-2 inhibitors to evaluate their effects and may improve the safety profiles. In addition, recent studies have suggested that rofecoxib's adverse cardiac events may not be a class effect but rather related to its particular chemical structure [17]. For this reason novel scaffolds with high selectivity for COX-2 inhibition need to be found and evaluated for their biological activities. In this regard, several selective COX-2 inhibitors with geminal diaryl groups (see structures A, B) have been reported that exhibited considerable potency and selectivity on COX-2 inhibition [18]. As part of our research program, aimed at discovering new selective COX-2 inhibitors, we focused our attention on the synthesis, COX inhibitory and some molecular modeling studies of 5,5-diarylhydantoin derivatives possessing a methylsulfonyl COX-2 pharmacophore at the para position of the C-5 phenyl ring. In these designed compounds we utilized geminal diarylhydantoin as new scaffold of COX-2 inhibitors. 
<smiles>Cc1ccc(-c2cc(C(F)(F)F)nn2-c2ccc(S(N)(=O)=O)cc2)cc1</smiles>

Celecoxib<smiles>NS(=O)(=O)c1ccc(C(=C2CCOC2=O)c2ccc(Cl)cc2)cc1</smiles>

A<smiles>CS(=O)(=O)c1ccc(C2=C(c3ccccc3)C(=O)OC2)cc1</smiles>

Rofecoxib<smiles>CS(=O)(=O)c1ccc(C(=C2CCCC2)c2ccc(F)cc2)cc1</smiles>

B<smiles>[R]N1C(=O)NC(c2ccccc2)(c2ccc(S(C)(=O)=O)cc2)C1=O</smiles>

designed compounds

Fig. 1. Some representative examples of selective COX-2 inhibitors and our designed compounds.

\section{Results and Discussion}

The target 5,5-diarylhydantoin derivatives 4-8 were synthesized via the route outlined in Scheme 1. As illustrated in the Scheme 1, 1-[4-(methylthio)phenyl]-2-phenylethanone (1) was synthesized by Friedel-Crafts acylation of thioanisole with phenylacetyl chloride (yield 75\%) [19]. Oxidation of 1 with selenium dioxide in dioxane-water under reflux condition gave 1-[4-(methylthio)phenyl]-2-phenylethane-1,2-dione (2) (yield 92\%) [19]. Reaction of 2 with urea under alkaline condition afforded 5-[4-(methylsulfanyl)phenyl]-5-phenylhydantoin (3, yield: 37\%) [20]. Oxidation of 3 with oxone in THF-water gave the oxidized methylsulfonyl compound 4 (yield 67\%) [21].The alkylated hydantoin derivatives 5-8 were prepared using an appropriate alkyl halide in alkaline ethanol (yield: 27-54\%) [22]. The purity of all products was determined by thin layer chromatography using several solvent systems of different polarity. All compounds were pure and stable. The compounds were characterized by NMR, infrared, mass spectrometry and CHN analysis. 


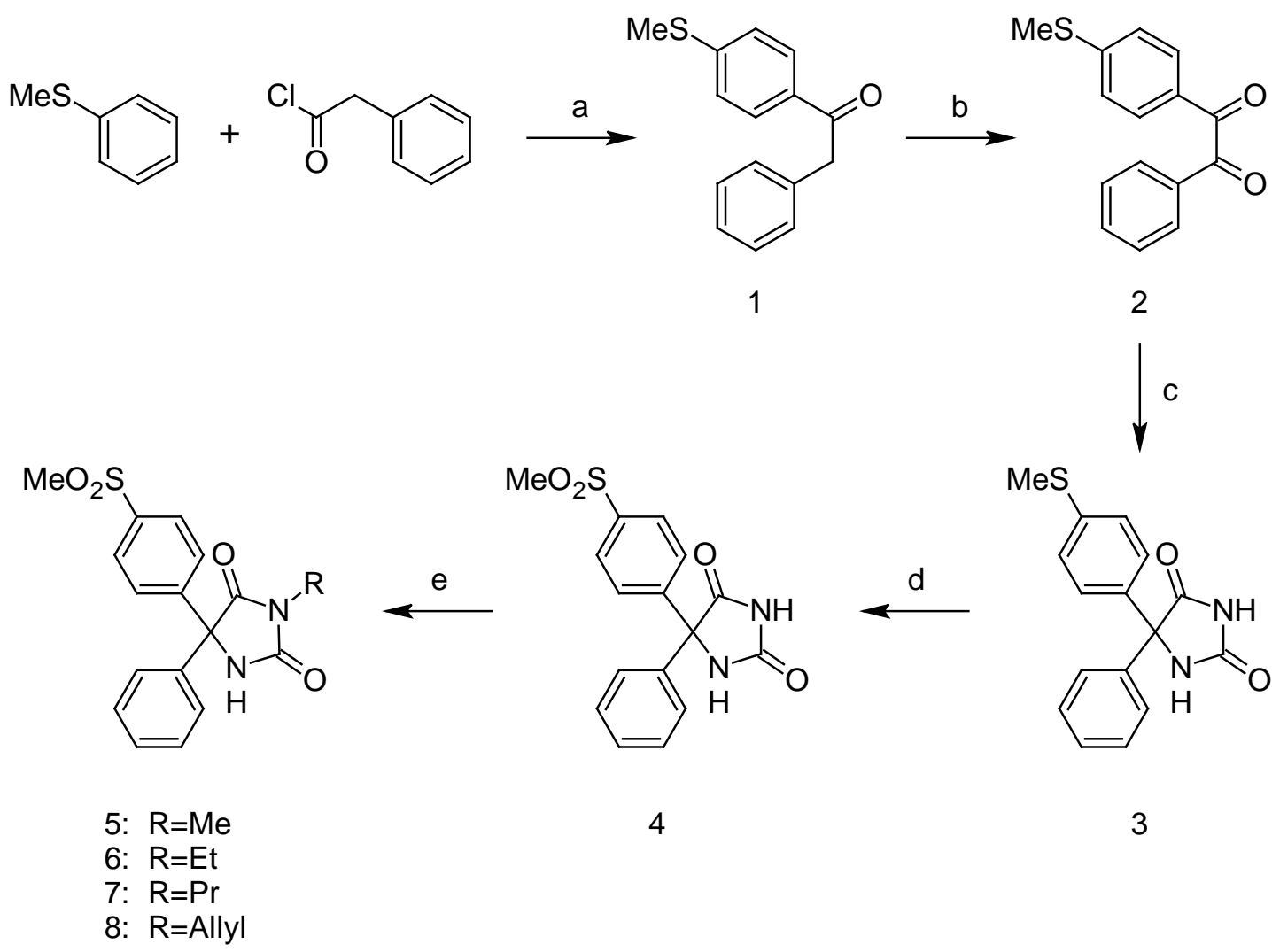

Sch. 1. Reagents and conditions: (a) $\mathrm{AlCl}_{3}, \mathrm{CH}_{2} \mathrm{Cl}_{2}, 0-25^{\circ} \mathrm{C}, 2 \mathrm{~h}$ (b) $\mathrm{SeO}_{2}$, dioxane$\mathrm{H}_{2} \mathrm{O}$, reflux, $1 \mathrm{~h}$ (c) urea, $30 \%$ aqueous $\mathrm{NaOH}$, EtOH, reflux, $3 \mathrm{~h}$ (d) oxone, THF- $\mathrm{H}_{2} \mathrm{O}, 25^{\circ} \mathrm{C}, 3 \mathrm{~h}$ (e) RI or $\mathrm{RBr}, \mathrm{K}_{2} \mathrm{CO}_{3} / \mathrm{DMF}, 10-30 \mathrm{~min}$.

All of the prepared 5,5-diarylhydantoin derivatives having different substituents at the N-3 hydantoin ring were evaluated to investigate the effect of different alkyls on COX-2 selectivity and potency. The ability of the 5,5-diarylhydantoin 4-8 to inhibit the COX-1 and COX-2 isozymes was determined using chemiluminescent enzyme assays (see enzyme inhibition data in Table 1.) according to our previously reported method [23]. In vitro COX1/COX-2 inhibition studies showed that all compounds 4-8 were selective inhibitors of the COX-2 isozyme with $\mathrm{IC}_{50}$ values in the highly potent 0.077 to $0.171 \mu \mathrm{M}$ range, and COX-2 selectivity indexes (S.I.) in the 70.2 to $>1298$ range. The relative COX-2 selectivity profiles for the 5,5-diarylhydantoin derivatives 4-8, with respect to the N-3 substituent $(R)$ was $H>$ $\mathrm{Me}>\mathrm{Et}>\mathrm{Allyl}>\mathrm{Pr}$. SAR data ( $\mathrm{IC}_{50}$ values) acquired by determination of the in vitro ability of the title compounds to inhibit the COX-1 and COX-2 isozymes showed that the COX inhibition is sensitive to the size of substituent at the N-3 hydantoin ring. These data showed that the type of substituent attached to N-3 of hydantoin ring affected selectivity for COX-2 inhibitory activity. Accordingly, compounds having larger groups at the N-3 central ring showed less selectivity for COX-2 isozyme that can be explained by steric parameter. However, among the 5,5-diarylhydantoin derivatives, compound 4 with no substituent at $\mathrm{N}-3$ hydantoin ring exhibited the highest COX-2 inhibitory selectivity $\left(\mathrm{COX}-2 \mathrm{IC}_{50}=0.077\right.$ $\mu \mathrm{M} ; \mathrm{SI}>1298)$ that was more selective than the reference drug celecoxib $\left(\mathrm{COX}-2 \mathrm{IC}_{50}=\right.$ $0.060 \mu \mathrm{M} ; \mathrm{SI}=405)$. In addition, our results showed that the unsubstituted compound 4 had significantly higher selectivity index compared with the alkylated analogues 5-8. This difference is mainly due to poor affinity of compound 4 for COX-1 (COX-1 IC $\mathrm{C}_{50}>100 \mu \mathrm{M}$; 
SI > 1298) comparison to alkylated hydantoins which showed more activities for COX-1 inhibition. Our in vitro enzyme inhibition data also showed that the size of N-3-alkyl is important for COX-1 inhibitory activity and therefore it can affect the selectivity index. In addition to steric parameter, the unsubstituted hydantoin $\mathbf{4}$ is more acidic than the alkylated compounds and therefore it can be as keto-enol forms. This effect may cause different tautomer forms for compound 4 and may explain its different interaction in COX-1 active site relative to its 3-alkylated derivatives. Accordingly, the binding interactions of the most potent and selective COX-2 inhibitor compound (4) within the COX-2 binding site were investigated. The most stable enzyme-ligand complex of 5-(4-methylsulfonyl) phenyl5-phenyl-hydantoin (4) possessing a $\mathrm{MeSO}_{2} \mathrm{COX}-2$ pharmacophore at para position of C-5 phenyl ring within the COX-2 binding site (Fig. 2) shows that the $p$-MeSO $\mathrm{M}_{2}-$ phenyl moiety is oriented towards the COX-2 secondary pocket ( $\mathrm{Arg}^{513}, \mathrm{Phe}^{518}$ and $\mathrm{Val}^{523}$ ). One of the $\mathrm{O}$-atoms of $p-\mathrm{MeSO}_{2}$ substituent forms a hydrogen binding interaction with amino group of $\operatorname{Arg}^{513}$ (distance $=4.6 \mathrm{~A}^{\circ}$ ) whereas the other $\mathrm{O}$-atom is about $3.5 \AA$ away from $\mathrm{NH}$ of $\mathrm{Arg}^{513}$. In addition, a hydrogen bonding interaction can form between the $\mathrm{NH}$ group at position 3 of hydantoin ring and nitrogen atoms of $\operatorname{Arg}^{120}$ (distance $=4.8 \AA$ ) which may explain the high potency and selectivity of compound 4. In this regard, a similar molecular modeling study was performed where compounds 4 and 5 were docked in the COX-1 binding site (Fig. 3) to explain the difference COX-1 activities of compound 4 and alkylated compounds such as 5 . Our results indicated that the most stable enzyme-ligand complex of N-3-methyl-5-(4-(methylsulfonyl)phenyl)-5-phenylhydantoin (5) well docked in the COX1 active site whereas the unsubstituted compound $\mathbf{4}$ was not docked into the active site of COX-1 as well as its alkylated analogue $\mathbf{5}$. These results can facilitate the interpretation of in vitro enzyme inhibition structure-activity data.

Tab 1. In vitro COX-1 and COX-2 enzyme inhibition assay data for 5,5-diarylhydantoin derivatives 4-8

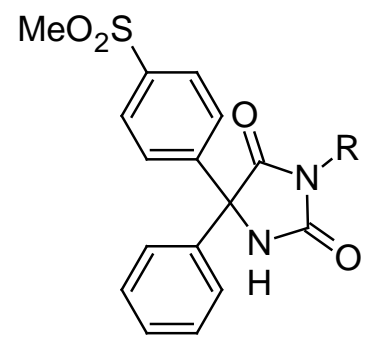

\begin{tabular}{|c|c|c|c|c|}
\hline \multirow[t]{2}{*}{ Compound } & \multirow[t]{2}{*}{$\mathbf{R}$} & \multicolumn{2}{|c|}{$I C_{50}(\mu M)^{a}$} & \multirow{2}{*}{$\begin{array}{l}\text { Selectivity } \\
\text { index (SI) }\end{array}$} \\
\hline & & COX-1 & COX-2 & \\
\hline 4 & $\mathrm{H}$ & $>100$ & 0.077 & $>1298$ \\
\hline 5 & $\mathrm{Me}$ & 22.69 & 0.081 & 280.1 \\
\hline 6 & Et & 20.21 & 0.098 & 206.2 \\
\hline 7 & $\mathrm{Pr}$ & 12.01 & 0.171 & 70.2 \\
\hline 8 & Allyl & 14.96 & 0.099 & 151.1 \\
\hline Celecoxib & - & 24.3 & 0.060 & 405 \\
\hline \multicolumn{5}{|c|}{$\begin{array}{l}\text { a Values are means of two determinations acquired using an } \\
\text { ovine COX-1/COX- } 2 \text { assay kit and the deviation from the mean is } \\
<10 \% \text { of the mean value. }{ }^{b} \text { In vitro COX-2 selectivity index } \\
\left(\text { COX-1 IC } \text { C }_{50} / \text { COX- } 2 \mid C_{50}\right) \text {. }\end{array}$} \\
\hline
\end{tabular}




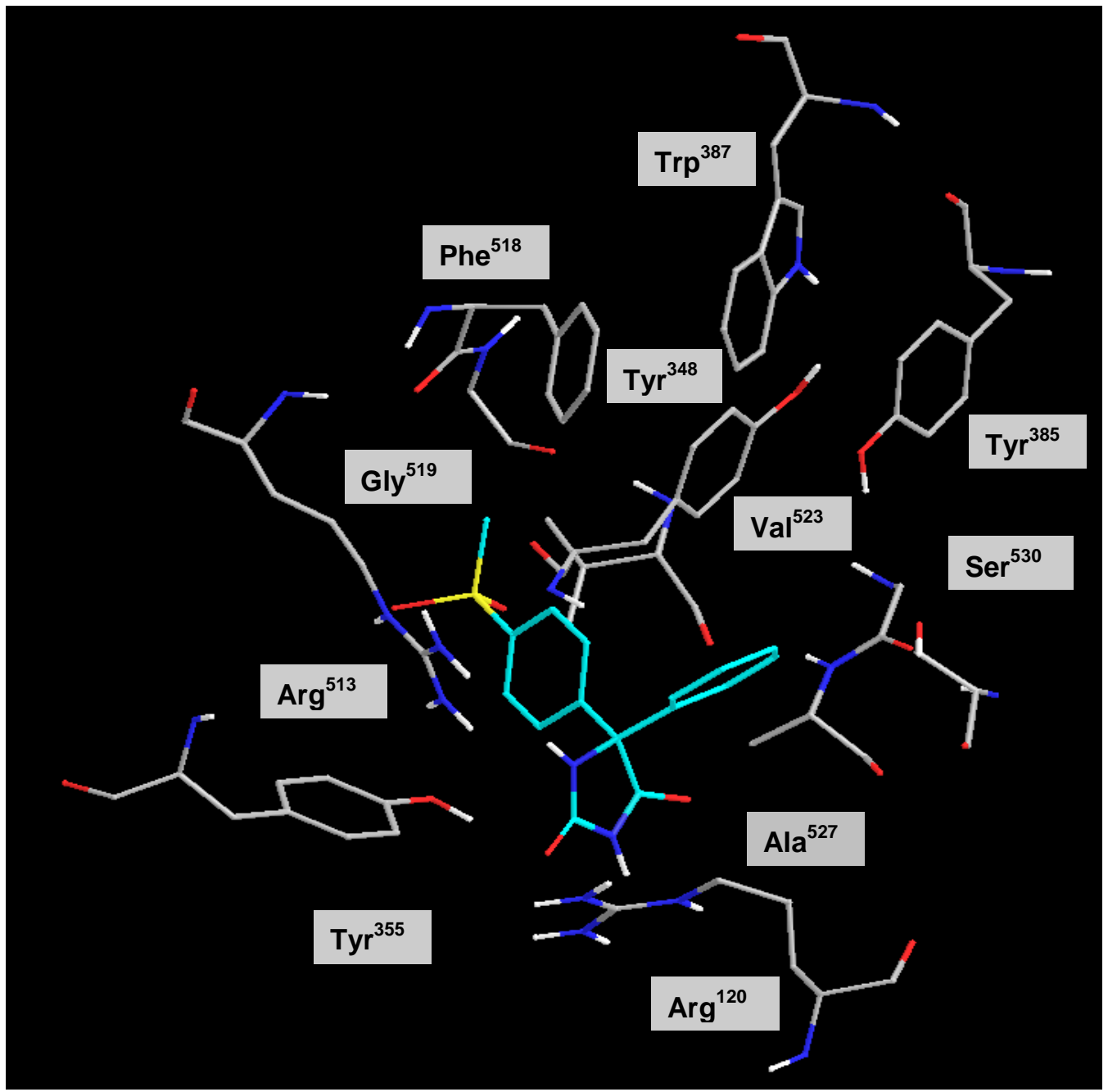

Fig. 2. Docking of 4 in the active site of murine COX-2.

\section{Conlcusion}

This study indicates that (i) the hydantoin ring is a suitable scaffold to design COX-2 inhibitors, (ii) COX-2 selectivity index is sensitive to the type of N-3 hydantoin substituent, and (iii) 5-[4-(methylsulfonyl)phenyl]-5-phenyl-hydantoin (4) exhibited high COX-2 inhibitory potency and selectivity.

\section{Experimental}

\section{Chemistry}

All chemicals and solvents used in this study were purchased from Merck AG and Aldrich Chemical. Melting points were determined with a Thomas-Hoover capillary apparatus. Infrared spectra were acquired using a Perkin Elmer Model 1420 spectrometer. A Bruker FT-500 MHz instrument (Bruker Biosciences, USA) was used to acquire ${ }^{1} \mathrm{HNMR}$ spectra with TMS as internal standard. Chloroform-D and DMSO-D 6 were used as solvents. Coupling constant $(\mathrm{J})$ values are estimated in hertz $(\mathrm{Hz})$ and spin multiples are given as $\mathrm{S}$ (singlet), d (double), t (triplet), q (quartet), m (multiplet), and br (broad). Low-resolution mass spectra were acquired with a MAT CH5/DF (Finnigan) mass spectrometer that was 
coupled online to a Data General DS 50 data system. Electron-impact ionization was performed at an ionizing energy of $70 \mathrm{eV}$ with a source temperature of $250{ }^{\circ} \mathrm{C}$. A 6410 Agilent LCMS triple quadrupole mass spectrometer (LCMS) with an electrospray ionization (ESI) interface was also used for molecular weight measurement. Microanalyses, determined for $\mathrm{C}, \mathrm{H}$, and $\mathrm{N}$ were within $\pm 0.4 \%$ of theoretical values.

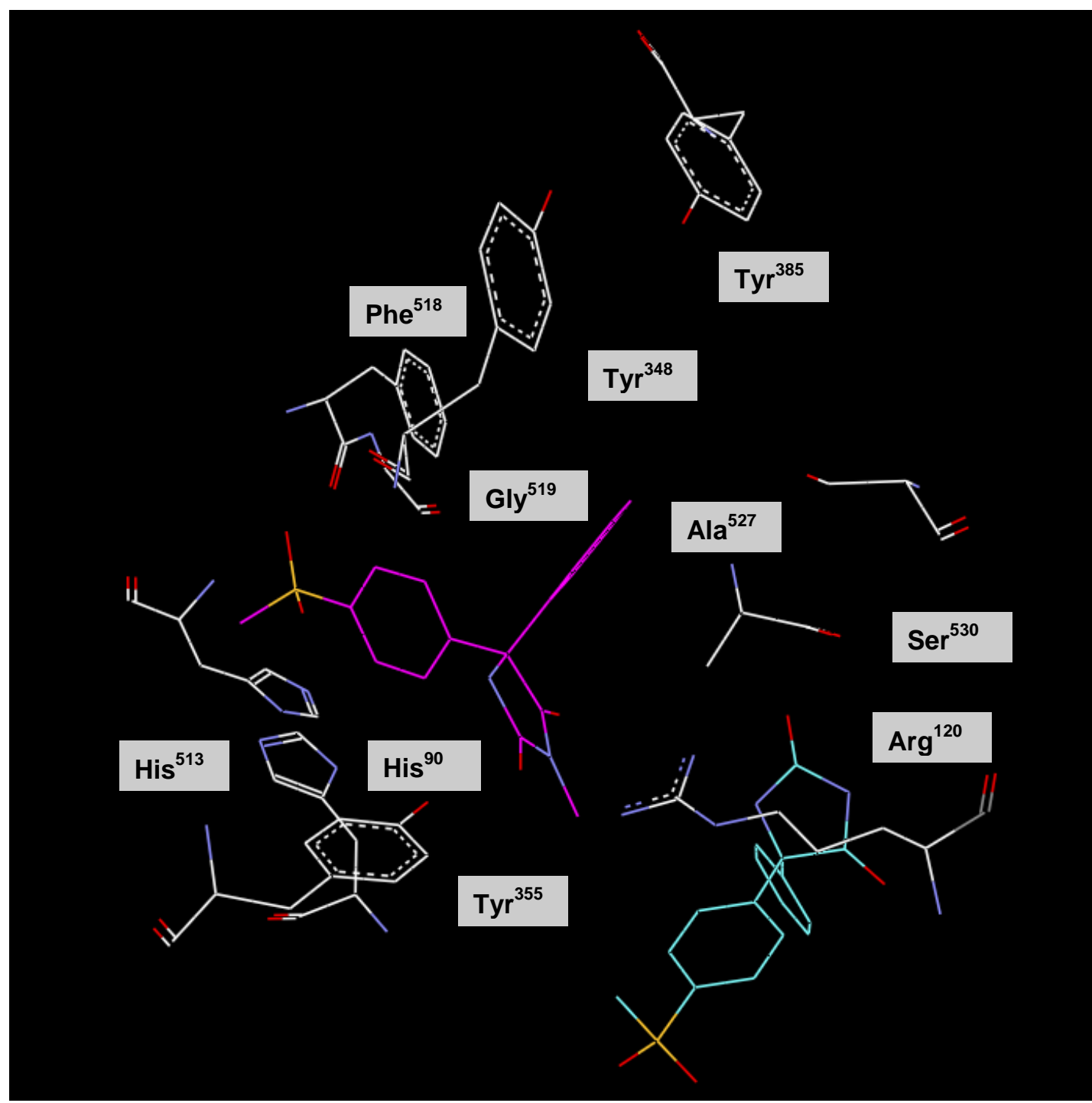

Fig. 3. Docking of $\mathbf{4}$ (in blue) and $\mathbf{5}$ (in pink) in the active site of murine COX-1.

\section{1-[4-(Methylsulfanyl)phenyl]-2-phenylethanone (1)}

Phenacetyl chloride ( $4 \mathrm{ml}, 30.2 \mathrm{mmol})$ was added to a suspension of anhydrous aluminum chloride $(4.2 \mathrm{~g}, 31.6 \mathrm{mmol})$ in dry dichloromethane $(50 \mathrm{ml})$ under argon atmosphere at $0{ }^{\circ} \mathrm{C}$. After stirring the reaction mixture for $30 \mathrm{~min}$, thioanisole $(3 \mathrm{ml}, 24 \mathrm{mmol})$ was slowly added during $15 \mathrm{~min}$. After keeping the mixture at this temperature for $2 \mathrm{hrs}$, it was allowed to stir at room temperature overnight. Then the mixture was poured over crushed ice and extracted with dichloromethane $(3 \times 50 \mathrm{ml})$, and the combined organic layer after washing with water was dried by anhydrous $\mathrm{MgSO}_{4}$ and evaporated. The solid product was recrystalized in ethanol. Yield: 75\%; mp: 97-98 ${ }^{\circ} \mathrm{C}$; IR (KBr): v (cm $\left.{ }^{-1}\right) 1685$ (CO), ${ }^{1} \mathrm{HNMR}$ 
$\left(\mathrm{CDCl}_{3}\right): \delta(\mathrm{ppm}) 2.52$ (s, 3H, SMe), 4.22 (s, 2H, $\left.\mathrm{CH}_{2}\right), 7.21-7.33\left(\mathrm{~m}, 7 \mathrm{H}\right.$, Phenyl $\mathrm{H}_{2}-\mathrm{H}_{6}$ \& 4-methylthiophenyl $\mathrm{H}_{3} \& \mathrm{H}_{5}$ ), 7.91 (d, 2H, 4-methylthiophenyl $\mathrm{H}_{2}$ \& $\mathrm{H}_{6}, J=8.4 \mathrm{~Hz}$ ). LC-MS (ESI) $\mathrm{m} / \mathrm{z}: 243.1(\mathrm{M}+1)(100)$.

\section{1-[4-(Methylsulfanyl)phenyl]-2-phenylethane-1,2-dione (2)}

Selenium dioxide $(2.5 \mathrm{~g}, 22.5 \mathrm{mmol})$ was dissolved in a mixture of 1,4-dioxane-water (50 ml, 48:2). The 1,4-dioxane solution of 1 (2.5 g, $10.3 \mathrm{mmol})$, was added to the reaction mixture and refluxed overnight. The precipitated selenium was filtered off and the filtrate was poured over ice water. After extraction with ethyl acetate $(3 \times 50 \mathrm{ml})$ the combined organic phase was washed with water, dried and evaporated to get yellow solid and crystallized in ethanol. Yield: 92\%; $\mathrm{mp}$ : 58-59 ${ }^{\circ} \mathrm{C}$; IR $(\mathrm{KBr}): \mathrm{v}\left(\mathrm{cm}^{-1}\right)$ 1675, 1586 (CO); ${ }^{1} \mathrm{HNMR}\left(\mathrm{CDCl}_{3}\right): \delta(\mathrm{ppm}) 2.62(\mathrm{~s}, 3 \mathrm{H}, \mathrm{SMe}), 7.13-7.42\left(\mathrm{~m}, 7 \mathrm{H}\right.$, Phenyl $\mathrm{H}_{2}-\mathrm{H}_{6}$ \& 4-methylthiophenyl $\mathrm{H}_{3}$ \& $\mathrm{H}_{5}$ ), 8.06 (d, 2H, 4-methylthiophenyl $\mathrm{H}_{2} \& \mathrm{H}_{6}, \mathrm{~J}=8.3 \mathrm{~Hz}$ ); LC-MS (ESI) $\mathrm{m} / \mathrm{z}$ : $257.1(\mathrm{M}+1)(100)$.

\section{5-[4-(Methylsulfanyl)phenyl]-5-phenylimidazolidine-2,4-dione (5-[4-(Methylthio)phenyl]-5-phenylhydantoin, 3)}

A solution of $2(1.5 \mathrm{~g}, 5.8 \mathrm{mmol})$ and urea $(0.4 \mathrm{~g}, 6.7 \mathrm{mmol})$ in $30 \%$ aqueous sodium hydroxide and ethanol $(50 \mathrm{ml})$ acid was refluxed for 3 hours. The reaction mixture was then cooled and poured into ice-cold water. The mixture was filtered and the filtrate was acidified with concentrated hydrochloric acid, cooled in ice-water and the precipitated product was filtered under vacuum. After washing with water, the product was crystallized in ethyl acetate Yield: 37\%; mp: 115-116 ${ }^{\circ} \mathrm{C}$; IR (KBr): v $\left(\mathrm{cm}^{-1}\right)$ 3568, $3287(\mathrm{NH}), 1709$ (CO), ${ }^{1} \mathrm{HNMR}\left(\mathrm{CDCl}_{3}\right): \delta(\mathrm{ppm}) 2.42(\mathrm{~s}, 3 \mathrm{H}, \mathrm{SMe}), 7.24-7.32\left(\mathrm{~m}, 7 \mathrm{H}\right.$, Phenyl $\mathrm{H}_{2}-\mathrm{H}_{6}$ \& 4methylthiophenyl $\mathrm{H}_{3}$ \& $\left.\mathrm{H}_{5}\right), 7.36$ (d, 2H, 4-methylthiophenyl $\mathrm{H}_{2}$ \& $\mathrm{H}_{6}, \mathrm{~J}=8.2 \mathrm{~Hz}$ ); LC-MS (ESI) m/z: $299.1(\mathrm{M}+1)$ (100); Anal. Calcd. for $\mathrm{C}_{16} \mathrm{H}_{14} \mathrm{~N}_{2} \mathrm{O}_{2} \mathrm{~S}$ : C, 64.41; $\mathrm{H}, 4.73 ; \mathrm{N}, 9.39$. Found: C, 64.62; H, 4.99; N, 9.22.

\section{5-[4-(Methylsulfonyl)phenyl]-5-phenylimidazolidine-2,4-dione (5-[4-(Methylsulfonyl)phenyl]-5-phenylhydantoin, 4)}

$0.5 \mathrm{~g}$ (1.7 mmol) of hydantoin 3 was dissolved in $10 \mathrm{ml}$ THF and $2.5 \mathrm{~g}$ oxone in THF/water was added. The mixture was stirred at room temperature for 4 hours, after evaporation of THF, the residue was extracted with ethyl acetate and dried with sodium sulfate and then evaporated. The product was recrystallized in ethanol. Yield: 67\%; mp: $223-224{ }^{\circ} \mathrm{C}$; IR $(\mathrm{KBr}): \vee\left(\mathrm{cm}^{-1}\right)$ 3210, $3100(\mathrm{NH}), 1727,1706(\mathrm{CO}), 1307,1154\left(\mathrm{SO}_{2}\right) ;{ }^{1} \mathrm{HNMR}\left(\mathrm{CDCl}_{3}\right): \delta$ (ppm) 3.18 (s, 3H, SO $\left.{ }_{2} \mathrm{Me}\right), 7.29-7.40$ (m, 5H, Phenyl), 7.59 (d, 2H, 4-methylsufonylphenyl $\mathrm{H}_{2}$ \& $\left.\mathrm{H}_{6}, \mathrm{~J}=8.4 \mathrm{~Hz}\right), 7.97$ (d, 2H, 4-methylsufonylphenyl $\mathrm{H}_{3}$ \& $\left.\mathrm{H}_{5}, \mathrm{~J}=8.4 \mathrm{~Hz}\right) ; 9.42(\mathrm{~s}, 1 \mathrm{H}$, $\mathrm{NH}), 11.23(\mathrm{~s}, 1 \mathrm{H}, \mathrm{NH}) ;{ }^{13} \mathrm{C}-\mathrm{NMR}\left(\mathrm{CDCl}_{3}\right)$ : $\delta 44.1,71.1,126.1,128.3,128.7,129.4,129.6$, 136.2, 139.8, 144.9, 157.0, 174.6; LC-MS (ESI) m/z: 331.1 (M+1) (100); Anal. Calcd. for $\mathrm{C}_{16} \mathrm{H}_{14} \mathrm{~N}_{2} \mathrm{O}_{4} \mathrm{~S}$ : C, 58.17; $\mathrm{H}, 4.27$; N, 8.48. Found: $\mathrm{C}, 58.33 ; \mathrm{H}, 4.59 ; \mathrm{N}, 8.32$.

\section{General Procedure for the Synthesis of N-3-alkylated hydantoins 5-8}

$1 \mathrm{mmol}$ of 4 was dissolved in the suspension of DMF/ $\mathrm{K}_{2} \mathrm{CO}_{3}(1.1 \mathrm{mmol})$ and $1 \mathrm{mmol}$ of alkyl halide (iodomethane, iodoethane, propyl bromide and allyl bromide) was added and the mixture was stirred at room temperature until TLC indicated that started material had been consumed (the duration of vortex was controlled to avoid alkylation of the second nitrogen site). Then, the reaction mixture was added to three volumes of cold water and 
extracted with ethyl acetate. The ethyl acetate extracts were washed with $5 \% \mathrm{NaOH}$, water, and dried over Na2SO4. The solvent was removed and the product crystallized in ethanol (yields: 27-54\%).

3-Methyl-5-[4-(methylsulfonyl)phenyl]-5-phenylimidazolidine-2,4-dione

(N-3-Methyl-5-(4-(methylsulfonyl)phenyl)-5-phenylhydantoin, 5)

Yield: 29\%; mp: 212-214 ${ }^{\circ} \mathrm{C}$; IR ( $\left.\mathrm{KBr}\right): \mathrm{v}\left(\mathrm{cm}^{-1}\right) 3230(\mathrm{NH}), 1707$ (CO),1313, $1153\left(\mathrm{SO}_{2}\right)$; ${ }^{1} \mathrm{HNMR}\left(\mathrm{CDCl}_{3}\right): \delta(\mathrm{ppm}) 3.09\left(\mathrm{~s}, 3 \mathrm{H}, \mathrm{CH}_{3}\right), 3.15\left(\mathrm{~s}, 3 \mathrm{H}, \mathrm{SO}_{2} \mathrm{Me}\right), 6.57(\mathrm{~s}, 1 \mathrm{H}, \mathrm{NH}), 7.29-$ $7.44\left(\mathrm{~m}, 5 \mathrm{H}\right.$, Phenyl), 7.69 (d, 2H, 4-methylsufonylphenyl $\mathrm{H}_{2}$ \& $\left.\mathrm{H}_{6}, \mathrm{~J}=8.4 \mathrm{~Hz}\right), 7.98(\mathrm{~d}, 2 \mathrm{H}$, 4-methylsufonylphenyl $\mathrm{H}_{3} \& \mathrm{H}_{5}, \mathrm{~J}=8.4 \mathrm{~Hz}$ ); $9.42(\mathrm{~s}, 1 \mathrm{H}, \mathrm{NH}), 11.23(\mathrm{~s}, 1 \mathrm{H}, \mathrm{NH}) ;{ }^{13} \mathrm{C}-\mathrm{NMR}$ $\left(\mathrm{CDCl}_{3}\right): \delta$ 29.8, 44.3, 69.4, 126.2, 128.3, 128.5, 129.4, 129.6, 136.5, 139.9, 144.5, 156.7, 163.1; LC-MS (ESI) m/z: 345.1 (M+1) (100); Anal. Calcd. for $\mathrm{C}_{17} \mathrm{H}_{16} \mathrm{~N}_{2} \mathrm{O}_{4} \mathrm{~S}$ : C, 59.29; $\mathrm{H}$, 4.68; N, 8.13. Found: C, 59.53; H, 4.89; N, 8.01.

3-Ethyl-5-[4-(methylsulfonyl)phenyl]-5-phenylimidazolidine-2,4-dione (N-3-Ethyl-5-(4-(methylsulfonyl)phenyl)-5-phenylhydantoin, 6)

Yield: 54\%; mp: 91-92 ${ }^{\circ} \mathrm{C}$; IR ( $\left.\mathrm{KBr}\right): \mathrm{v}\left(\mathrm{cm}^{-1}\right) 3302(\mathrm{NH}), 1709$ (CO),1310, $1148\left(\mathrm{SO}_{2}\right)$; ${ }^{1} \mathrm{HNMR}\left(\mathrm{CDCl}_{3}\right): \delta(\mathrm{ppm}) 1.30\left(\mathrm{t}, 3 \mathrm{H}, \mathrm{CH}_{3}, \mathrm{~J}=7.1 \mathrm{~Hz}\right), 3.10\left(\mathrm{~s}, 3 \mathrm{H}, \mathrm{SO}_{2} \mathrm{Me}\right), 3.70(\mathrm{q}, 2 \mathrm{H}$, $\left.\mathrm{CH}_{2}, \mathrm{~J}=7.1 \mathrm{~Hz}\right), 6.79(\mathrm{~s}, 1 \mathrm{H}, \mathrm{NH}), 7.29-7.43(\mathrm{~m}, 5 \mathrm{H}$, Phenyl), 7.69 (d, 2H, 4-methylsufonylphenyl $\mathrm{H}_{2}$ \& $\left.\mathrm{H}_{6}, \mathrm{~J}=8.4 \mathrm{~Hz}\right), 7.98\left(\mathrm{~d}, 2 \mathrm{H}\right.$, 4-methylsufonylphenyl $\mathrm{H}_{3}$ \& $\mathrm{H}_{5}, \mathrm{~J}=8.4 \mathrm{~Hz}$ ); ${ }^{13} \mathrm{C}-\mathrm{NMR}\left(\mathrm{CDCl}_{3}\right): \delta 12.6,35.8,44.2,69.6,126.3,128.3,128.6,129.5,129.7,136.6$, 139.9, 144.5, 156.7, 163.1; LC-MS (ESI) m/z: $359.1(\mathrm{M}+1)(100)$; Anal. Calcd. for $\mathrm{C}_{18} \mathrm{H}_{18} \mathrm{~N}_{2} \mathrm{O}_{4} \mathrm{~S}$ : C, 60.32; $\mathrm{H}, 5.06 ; \mathrm{N}, 7.82$. Found: $\mathrm{C}, 60.12 ; \mathrm{H}, 5.31 ; \mathrm{N}, 8.05$.

5-[4-(Methylsulfonyl)phenyl]-5-phenyl-3-propylimidazolidine-2,4-dione (5-(4-(Methylsulfonyl)phenyl)-5-phenyl-N-3-propyl-hydantoin, 7)

Yield: 47\%; mp: $82-83^{\circ} \mathrm{C}$; IR (KBr): v $\left(\mathrm{cm}^{-1}\right) 3302(\mathrm{NH}), 1700(\mathrm{CO}), 1310,1150\left(\mathrm{SO}_{2}\right)$; ${ }^{1} \mathrm{HNMR}\left(\mathrm{CDCl}_{3}\right): \delta(\mathrm{ppm}) 0.95\left(\mathrm{t}, 3 \mathrm{H}, \mathrm{CH}_{3}, \mathrm{~J}=7.4 \mathrm{~Hz}\right), 1.72\left(\mathrm{~m}, 2 \mathrm{H}, \mathrm{CH}_{2}\right), 3.09(\mathrm{~s}, 3 \mathrm{H}$, $\mathrm{SO}_{2} \mathrm{Me}$ ), $3.60\left(\mathrm{t}, 2 \mathrm{H}, \mathrm{CH}_{2} \mathrm{~N}, \mathrm{~J}=7.3 \mathrm{~Hz}\right), 6.38(\mathrm{~s}, 1 \mathrm{H}, \mathrm{NH}), 7.29-7.43$ (m, 5H, Phenyl), 7.69 (d, 2H, 4-methylsufonylphenyl $\mathrm{H}_{2}$ \& $\mathrm{H}_{6}, \mathrm{~J}=8.4 \mathrm{~Hz}$ ), 7.98 (d, 2H, 4-methylsufonylphenyl $\mathrm{H}_{3}$ \& $\left.\mathrm{H}_{5}, \mathrm{~J}=8.4 \mathrm{~Hz}\right) ;{ }^{13} \mathrm{C}-\mathrm{NMR}\left(\mathrm{CDCl}_{3}\right): \delta 11.2,19.6,44.1,44.4,69.1,126.4,128.3,128.7,129.5$, 129.7, 136.7, 139.7, 144.7, 156.6, 162.1; LC-MS (ESI) m/z: 373.1 (M+1) (100); Anal. Calcd. for $\mathrm{C}_{19} \mathrm{H}_{20} \mathrm{~N}_{2} \mathrm{O}_{4} \mathrm{~S}$ : C, 61.27; $\mathrm{H}, 5.41 ; \mathrm{N}, 7.52$. Found: C, 61.52; $\mathrm{H}, 5.01 ; \mathrm{N}, 7.85$.

5-[4-(Methylsulfonyl)phenyl]-5-phenyl-3-(prop-2-en-1-yl)imidazolidine-2,4-dione (N-3-Allyl-5-(4-(methylsulfonyl)phenyl)-5-phenylhydantoin, 8)

Yield: 27\%; mp: 129-130 ${ }^{\circ} \mathrm{C}$; IR (KBr): v (cm-1) $3322(\mathrm{NH}), 1704(\mathrm{CO}), 1312,1152\left(\mathrm{SO}_{2}\right)$; ${ }^{1} \mathrm{HNMR}\left(\mathrm{CDCl}_{3}\right): \delta(\mathrm{ppm}) 3.10\left(\mathrm{~s}, 3 \mathrm{H}, \mathrm{SO}_{2} \mathrm{Me}\right), 4.20\left(\mathrm{~d}, 2 \mathrm{H}, \mathrm{CH}_{2} \mathrm{~N}, \mathrm{~J}=5.6 \mathrm{~Hz}\right), 5.22(\mathrm{~d}, 2 \mathrm{H}$, $\left.\mathrm{CH}_{2}, \mathrm{~J}=11.3 \mathrm{~Hz}\right), 5.85(\mathrm{~m}, 1 \mathrm{H}, \mathrm{CH}), 6.55(\mathrm{~s}, 1 \mathrm{H}, \mathrm{NH}), 7.29-7.42(\mathrm{~m}, 5 \mathrm{H}$, Phenyl), 7.69 (d, $2 \mathrm{H}$, 4-methylsufonylphenyl $\mathrm{H}_{2}$ \& $\left.\mathrm{H}_{6}, \mathrm{~J}=8.4 \mathrm{~Hz}\right), 7.94\left(\mathrm{~d}, 2 \mathrm{H}, 4\right.$-methylsufonylphenyl $\mathrm{H}_{3}$ \& $\left.\mathrm{H}_{5}, \mathrm{~J}=8.4 \mathrm{~Hz}\right) ;{ }^{13} \mathrm{C}-\mathrm{NMR}\left(\mathrm{CDCl}_{3}\right): \delta 44.1,69.3,117.1,126.3,128.2,128.6,129.4,129.7$, 134.7, 136.8, 139.9, 144.7, 156.8, 161.9; LC-MS (ESI) m/z: 371.1 (M+1) (100); Anal. Calcd. for $\mathrm{C}_{19} \mathrm{H}_{18} \mathrm{~N}_{2} \mathrm{O}_{4} \mathrm{~S}$ : C, 61.61; $\mathrm{H}, 4.90 ; \mathrm{N}, 7.56$. Found: C, 61.76; $\mathrm{H}, 5.11 ; \mathrm{N}, 7.25$.

\section{Docking Studies}

Docking studies were performed using Autodock software Version 3.0.5. The coordinates of the X-ray crystal structure of the selective COX-2 inhibitor SC-558 bound to the murine 
COX-2 enzyme was obtained from the RCSB Protein Data Bank (1cx2) and hydrogens were added. The ligand molecules were constructed using the Builder module and were energy minimized for 1000 iterations reaching a convergence of $0.01 \mathrm{kcal} / \mathrm{mol} \AA$. The energy minimized ligands were superimposed on SC-558 in the PDB file 1cx2 after which SC-558 was deleted. The purpose of docking is to search for favorable binding configuration between the small flexible ligands and the rigid protein. Protein residues with atoms greater than $7.5 \AA$ from the docking box were removed for efficiency. These docked structures were very similar to the minimized structures obtained initially. The quality of the docked structures was evaluated by measuring the intermolecular energy of the ligandenzyme assembly [24,25].

\section{Biological Assay}

The ability of the test compounds listed in Table 1 to inhibit ovine COX-1 and COX-2 (IC 50 value, $\mu \mathrm{M}$ ) was determined using chemiluminescent enzyme assays kit (Cayman Chemical, Ann Arbor, MI, USA) according to our previously reported method [23].

\section{Acknowledgement}

This work was financially supported by Research Deputy of Shahid Beheshti University of Medical sciences as part of thesis of Razieh Ghodsi.

\section{Authors' Statement}

The authors declare no conflict of interest.

\section{References}

[1] Vane JR. Inhibition of prostaglandin synthesis as a mechanism of action for aspirin-like drugs. Nat New Biol. 1971; 231: 232-239.

PMid:5284360

[2] Smith WL, DeWitt DL.

Prostaglandin endoperoxide $\mathrm{H}$ synthases-1 and -2 .

Adv Immunol. 1996; 62: 167-215. doi:10.1016/S0065-2776(08)60430-7

[3] Vane JR, Bakhle YS, Botting RM.

Cyclooxygenases 1 and 2.

Ann Rev Pharmacol Toxicol. 1998; 38: 98-120.

doi:10.1146/annurev.pharmtox.38.1.97

[4] Xie WL, Chipman JG, Robertson DL, Erikson RL, Simmons DL.

Expression of a mitogen-responsive gene encoding prostaglandin synthase is regulated by mRNA splicing.

Proc Natl Acad Sci U S A. 1991; 88: 2692-2696.

doi:10.1073/pnas.88.7.2692

[5] Vane JR, Botting RM.

Anti-inflammatory drugs and their mechanism of action.

Inflamm Res. 1998; 47: S78-S87.

doi:10.1007/s000110050284 
[6] Perini R, Fiorucci R, Wallace JL.

Mechanisms of nonsteroidal anti-inflammatory drug-induced gastrointestinal injury and repair: a window of opportunity for cyclooxygenase-inhibiting nitric oxide donors.

Can J Gastroenterol. 2004; 18: 229-236.

PMid:15054499

[7] Kawamori T, Rao CV, Seibert K, Reddy BS.

Chemopreventive activity of celecoxib, a specific cyclooxygenase-2 inhibitor, against colon carcinogenesis.

Cancer Res. 1998; 58: 409-412.

PMid:9458081

[8] Takkouche B, Regueira-Mendez C, Etminan M.

Breast cancer and use of nonsteroidal anti-inflammatory drugs: A metaanalysis.

J Nat Cancer Inst. 2008; 100: 1439-1447.

doi:10.1093/jnci/djn324

[9] Hernandez-Diaz S, Garcia Rodriguez LA.

Nonsteroidal anti-inflammatory drugs and risk of lung cancer.

Int J Cancer. 2007; 120: 1565-1572.

doi:10.1002/ijc.22514

[10] Srinath P, Rao PN, Knaus EE, Suresh MR.

Effect of cyclooxygenase-2 (COX-2) inhibitors on prostate cancer cell proliferation.

Anticancer Res. 2003; 23: 3923-3928.

PMid:14666698

[11] Van Gool WA, Aisen PS, Eikelenboom P.

Anti-inflammatory therapy in Alzheimer's disease: is hope still alive?

J Neurol. 2003; 250: 788-792.

doi:10.1007/s00415-003-1146-5

[12] Teismann P, Tieu K, Choi DK, Wu DC, Naini A, Hunot S, Vila M, Jackson-Lewis V, Przedborski S. Cyclooxygenase-2 is instrumental in Parkinson's disease neurodegeneration.

JAMA. 2003; 289: 2819-2826.

doi:10.1001/jama.289.21.2819

[13] Talley JJ.

Selective inhibitors of cyclooxygenase-2 (COX -2).

Prog Med Chem. 1999; 36: 201-234.

doi:10.1016/S0079-6468(08)70048-1

[14] Penning TD, Tally JJ, Bertenshaw SR, Carter JS, Collins PW, Doctor S, Graneto MJ, Lee LF, Malecha JW, Miyashiro JM, Rogers RS, Rogier DJ, Yu SS, Anderson GD, Burton EG, Cogburn JN, Gregory SA, Koboldt CM, Perkins WE, Seibert K, Veenhuizen AW, Zhang YY, Isakson PC. Synthesis and biological evaluation of the 1,5-diarylpyrazole class of cyclooxygenase-2 inhibitors: identification of 4-[5-(4-methylphenyl)-3- (trifluoromethyl)-1H-pyrazol-1-yl]benzenesulfonamide (SC58635, celecoxib).

J Med Chem. 1997; 40:1347-1365.

doi:10.1021/jm960803q

[15] Prasit P, Wang Z, Brideau C, Chan CC, Charleson S, Cromlish W, Ethier D, Evans JF, FordHutchinson AW, Gauthier JY, Gordon R, Guay J, Gresser M, Kargman S, Kennedy B, Leblan Y, Leger S, Mancini J, O'Neill G.P, Quellet M, Percival MD, Perrier H, Riendeau, D, Rodger I, Tagari P, Therien M, Vickers P, Wong E, Xu LJ, Young RN, Zamboni R, Boyce S, Rupniak N, Forrest M, Visco D, Patrick D.

The discovery of rofecoxib, [MK 966, Vioxx, 4-(4'-methylsulfonylphenyl)-3-phenyl-2(5H)-furanone], an orally active cyclooxygenase-2-inhibitor.

Bioorg Med Chem Lett. 1999; 9: 1773-1778.

doi:10.1016/S0960-894X(99)00288-7 
[16] Mason RP, Walter MF, McNulty HP, Lockwood SF, Byun J, Day CA, Jacob RF.

Rofecoxib increases susceptibity of human LDL and membrane lipids to oxidative damage: A mechanism of cardiotoxicity.

J Cardivasc Pharmacol. 2006; 47: S7-S14.

doi:10.1097/00005344-200605001-00003

[17] Dogne JM, Hanson J, Supuran C, Pratico D.

Coxibs and cardiovascular side effects: From ligh to shadow.

Curr Pharm Des. 2006; 12: 971-975.

doi:10.2174/138161206776055949

[18] Kalgutkar AS, Zhao Z.

Discovery and design of selective cyclooxygenase-2 inhibitors as non-ulcerogenic, anti-inflammatory drugs with potential utility as anti-cancer agents.

Current Drug Targets. 2001; 2: 79-106.

doi:10.2174/1389450013348830

[19] Singh SK, Saibaba V, Ravikumar V, Rudrawar SV, Daga P, Seshagiri Rao C, Akhila V, Hegde P, Koteswar Rao Y.

Synthesis and biological evaluation of 2,3-diarylpyrazines and quinoxalines as selective COX-2 inhibitors.

Bioorg Med Chem. 2004; 12: 1881-1893.

doi:10.1016/j.bmc.2004.01.033

[20] Mahmoodi NO, Emadi S.

One-pot synthesis of phenytoin analogs.

Russ J Org Chem. 2004; 40: 377-382.

doi:10.1023/B:RUJO.0000034975.03943.bb

[21] Shafiee A, Naimi E, Mansoobi P, Foroumadi A, Shekari M.

Syntheses of substituted oxazolo -1,3,4-thiadiazoles, 1,3,4- oxadiazoles and 1,2,4-triazoles.

J Heterocycl Chem. 1995; 32: 1235-1239.

doi:10.1002/jhet.5570320424

[22] Zarghi A, Arfaee S, Rao PNP, Knaus EE.

Design, synthesis, and biological evaluation of 1,3-diarylprop-2-en-1-ones: A novel class of cyclooxygenase-2 inhibitors.

Bioorg Med Chem. 2006; 14: 2600-2605.

doi:10.1016/j.bmc.2005.11.041

[23] Zarghi A, Najafnia L, Daraee B, Dadrass OG, Hedayati M.

Synthesis of 2,3-diaryl-1,3-thiazolidine-4-one derivatives as selective cyclooxygenase (COX-2)

inhibitors.

Bioorg Med Chem Lett. 2007; 17: 5634-5637.

doi:10.1016/j.bmcl.2007.07.084

[24] Morris GM, Goodsell DS, Halliday RS, Huey R, Hart WE, Belew RK, Olson A.

Automated docking using a lamarkian genetic algorithm and an empirical binding free energy function. J Comput Chem. 1998; 19: 1639-1662.

doi:10.1002/(SICl)1096-987X(19981115)19:14<1639::AID-JCC10>3.0.CO;2-B

[25] Kurumbail RG, Stevens AM, Gierse JK, McDonald JJ, Stegeman RA, Pak JY, Gildehaus D, Miyashiro JM, Penning TD, Seibert K, Isakson PC, Stallings WC.

Structural basis for selective inhibition of cyclooxygenase-2 by anti-inflammatory agents.

Nature. 1996; 384: 644-648.

doi:10.1038/384644a0 